\title{
Natural variation of arsenic fractions in soils of the Brazilian Amazon
}

Ediu Carlos da Silva Júnior ${ }^{\text {a }}$, Gabriel Caixeta Martins ${ }^{\text {b }}$, Lúcia Helena de Oliveira Wadt ${ }^{\text {, }}$, Kátia Emídio da Silva ${ }^{\mathrm{d}}$, Roberval Monteiro Bezerra de Lima ${ }^{\mathrm{d}}$, Karine Dias Batista ${ }^{\mathrm{e}}$, Marcelino Carneiro Guedes ${ }^{\mathrm{f}}$, Raimundo Cosme de Oliveira Junior ${ }^{\mathrm{g}}$, André Rodrigues Reis ${ }^{\mathrm{h}}$, Guilherme Lopes ${ }^{\mathrm{a}}$, Michele Duarte de Menezes ${ }^{\mathrm{a}}$, Martin R. Broadley ${ }^{\text {i }}$, Scott D. Young ${ }^{\text {i }}$, Luiz Roberto Guimarães Guilherme ${ }^{\text {a,* }}$

a Department of Soil Science, Federal University of Lavras, Lavras, MG CEP 37200-000, Brazil

b Vale Institute of Technology, Belém, PA CEP 66055-090, Brazil

c Embrapa Rondônia, Porto Velho, RO CEP 76815-800, Brazil

d Embrapa Amazônia Ocidental, Manaus, AM CEP 69010-970, Brazil

e Embrapa Roraima, Boa Vista, RR CEP 69301-970, Brazil

f Embrapa Amapá, Macapá, AP CEP 68903-419, Brazil

g Embrapa Amazônia Oriental, Belém, PA CEP 66095-903, Brazil

h São Paulo State University (UNESP), School of Sciences and Engineering, Rua Domingos da Costa Lopes 780, Tupã, SP CEP 17602-496, Brazil

i School of Biosciences, University of Nottingham, Sutton Bonington Campus, Loughborough LE12 5RD, UK

\section{H I G H L I G H T S}

- Sena Madureira presents As concentration in soils higher than the prevention level.

- Average extractable As (soluble + available) corresponds to $0.24 \%$ of the total.

- Available As represents $>70 \%$ of the extractable As, on average.

- Arsenic fractions are mainly influenced by soil $\mathrm{pH}$ and are highly correlated with $\mathrm{Al}^{3+}$.

\section{G R A P H I C A L A B S T RACT}

Arsenic fractions in soils of the Brazilian Amazon



\begin{abstract}
A B S T R A C T
Arsenic (As) in native soils of the Amazon rainforest is a concern due to its likely origin from the Andean rivers, which transport loads of sediments containing substantial amounts of trace elements coming from the cordilleras. Yet, unveiling soil As baseline concentrations in the Amazon basin is still a need because most studies in Brazil have been performed in areas with predominantly high concentrations and cannot express a real baseline value for the region. In this study, 414 soil samples (0-20, 20-40 and 40-60 cm layers) were collected from different sites throughout the Amazon basin - including native Amazon rainforest and minimally disturbed areas and used to determine total and extractable (soluble + available) As concentrations along with relevant soil physicochemical properties. Descriptive statistics of the data was performed and Pearson correlation supported
\end{abstract}

\footnotetext{
* Corresponding author.

E-mail address: Guilherm@dcs.ufla.br (L.R.G. Guilherme).
} 
by a Principal Component Analysis (PCA) provided an improved understanding of where and how As concentrations are influenced by soil attributes. Total As concentration ranged from 0.98 to $41.71 \mathrm{mg} \mathrm{kg}^{-1}$ with values usually increasing from the topsoil $(0-20 \mathrm{~cm})$ to the deepest layer $(40-60 \mathrm{~cm})$ in all sites studied. Considering the proportional contribution given by each fraction (soluble and available) on extractable As concentration, it is noticeable that $\mathrm{KH}_{2} \mathrm{PO}_{4}$-extractable As represents the most important fraction, with $>70 \%$ of the As extracted on average in all the sites studied. Still, the extractable fractions (soluble + available) correspond to $\sim 0.24 \%$ of the total As, on average. Total, available, and soluble As fractions were strongly and positively correlated with soil $\mathrm{Al}^{3+}$. The PCA indicated that soil pH in combination with CEC might be the key factors controlling soil As concentrations and the occurrence of each arsenic fraction in the soil layers.

(C) 2019 Elsevier B.V. All rights reserved.

\section{Introduction}

Arsenic (As) occurs naturally in rocks, soil and water, with higher levels usually found close to sites with anthropogenic pollution, with special attention to groundwater in several countries in the world, with concentration levels exceeding the WHO drinking water guideline value of $10 \mu \mathrm{g} \mathrm{L}^{-1}$ (WHO, 2001; Chowdhury et al., 2018). Contamination has been detected in ground and surface water in 15 of the 20 Latin American countries in 2011, and much of the As contamination described during the last 20 years in this region were published much later or never in the international literature (Bundschuh et al., 2012).

The overall mean value of total As for different soils worldwide is estimated as $6.83 \mathrm{mg} \mathrm{kg}^{-1}$ (Kabata-Pendias, 2011), which is very close to the mean value found for Brazilian oxisols (i.e., $5.92 \mathrm{mg} \mathrm{kg}^{-1}$ ) (Campos et al., 2007). Yet, As is found more abundantly in argillaceous sediments (up to $13 \mathrm{mg} \mathrm{kg}^{-1}$ ). Anionic forms, $\mathrm{AsO}_{2}^{-}, \mathrm{HAsO}_{4}^{2-}$, and $\mathrm{H}_{2} \mathrm{AsO}_{3}^{2-}$, predominate in soil solution (Kabata-Pendias and Mukherjee, 2007).

Exposure to As has a great impact on human health across the world (Kapaj et al., 2006; Meliker et al., 2007; Chatterjee et al., 2018). In the environment As often raises a great concern because of its high toxicity to diverse human body systems (e.g. integumentary, nervous, respiratory, cardiovascular, hematopoietic, immune, endocrine, hepatic, renal, reproductive) as well as to its capability of causing different types of cancer (skin, lung, and bladder) (Abdul et al., 2015; Gamboa-Loira et al., 2017). In fact, this naturally occurring metalloid is considered a well-established "Class I" human carcinogen by the International Agency of Research on Cancer (IARC) (Minatel et al., 2018).

Arsenic contamination originating from geogenic sources occurs in many regions worldwide, such as Bangladesh and India (Arco-Lázaro et al., 2018; Rahman et al., 2018). It is estimated that over 200 million people are chronically exposed to As concentrations at or above the World Health Organization (WHO) threshold across the world (Naujokas et al., 2013). In addition to the natural occurrence of arsenic, there are many other anthropogenic sources that may increase soil arsenic concentration, for example: mining, smelting, application of wastes, animal manures, As-bearing pesticides, wood preservation, irrigation using contaminated water, coal fly ash, glass manufacturing, wastewater sludge, pharmaceutical waste, livestock dips and smelting activities to phosphate fertilizers (Punshon et al., 2017).

Several studies have clearly shown that the adverse effects of arsenic are not only dependent on the total concentration of this element, but rather on its reactive fractions (Wang et al., 2018). For As, this fractionation may include soluble and exchangeable, bound to carbonates, iron and manganese oxides, organic matter, sulphides and residual fraction among others. Those fractions govern arsenic bioavailability and mobility in soils (Ho et al., 2013; Shahmoradi et al., 2017; Liu et al., 2018). Additionally, soil physicochemical properties such as $\mathrm{pH}$, redox potential, clay and organic matter (OM) content and the presence of metal (Fe, $\mathrm{Mn}$ and/or Al) oxides and/or competing ions such as phosphates highly influence arsenic bioavailability and mobility (Sharma et al., 2010; Biswas et al., 2014).
Many sequential extraction procedures (SEP) can be used to extract chemical fractions of trace elements in soil (Wan et al., 2017; He et al., 2013). These methods classify trace elements in soil into different operationally-defined fractions with increasing metal binding strength (Wan et al., 2017). Soil chemical extractions for soluble and available As can help understand the element's dynamic chemical behavior and its possible entrance into the food chain.

Many extractants can be used for this purpose, for example, the soluble fraction can be extracted using water (water-soluble) (Wenzel et al., 2001; Baroni et al., 2004; Jiang et al., 2014; Wan et al., 2017). This fraction contains water-soluble species such as free arsenate, and weakly adsorbed species, representing the most mobile and potentially the most bioavailable As species in the environment (Wan et al., 2017). Additionally, the soluble fraction can be also extracted using inorganic salts such as $\mathrm{KCl}$ (Kim et al., 2003) and $\mathrm{KNO}_{3}$ (Alam et al., 2007).

Another relevant fraction of As - the available fraction - is not well defined in the literature in terms of method of extraction, but would be better classified as the As retained in the solid phase interacting with the soil solution and occupying exchangeable sites as diffuse ion or as outer-sphere complexes (Van Herreweghe et al., 2003) and can be extracted by using $\mathrm{Na}_{2} \mathrm{HPO}_{4}$ (Kim et al., 2003), $\mathrm{MgCl}_{2}$ (Jiang et al., 2014), $\mathrm{CH}_{3} \mathrm{COOH}$ (Wan et al., 2017), $\left(\mathrm{NH}_{4}\right)_{2} \mathrm{SO}_{4}$ (Wenzel et al., 2001) and $\mathrm{KH}_{2} \mathrm{PO}_{4}$ (Thinh et al., 2018) among others.

In Brazil, soil quality criteria for some contaminants were defined by CONAMA in the normative 420/2009, which sets screening values based on total concentration of selected elements. For arsenic, the established threshold for the so-called "prevention level" in soil was $15 \mathrm{mg} \mathrm{As} \mathrm{kg}{ }^{-1}$ and is primarily based on phytotoxicity tests and ecological risk assessment. Besides this, investigation/intervention values derived from human health risk assessments were set as $35 \mathrm{mg} \mathrm{As} \mathrm{kg}^{-1}$ for agricultural, $55 \mathrm{mg} \mathrm{As} \mathrm{kg}^{-1}$ for residential, and $150 \mathrm{mg} \mathrm{As} \mathrm{kg}^{-1}$ for industrial areas (Conama, 2009). These thresholds were established for total concentrations and in some situations can be very restrictive, especially in soils with low bioavailability. This justifies investing more effort to assess As availability in soils, especially in tropical ecosystems, which are known for their oxidic characteristics that render arsenic less bioavailable (Campos et al., 2007, 2013a).

Increased As levels have been observed in soils worldwide and also in Brazil, especially due to mining activities (Bundschuh et al., 2012). Hypothetically, we could expect high concentrations of As in soils nearby the Amazon basin because of the sediments coming through the Amazon river (and its tributaries) from the Andes, which are expected to be naturally enriched in selected volatile trace elements (e.g., Se and Hg) (Fadini and Jardim, 2001; Silva Junior et al., 2017). However, there is a lack of comprehensive information about background levels of As in soils from the Amazon basin to prove this assumption since the more recent studies have focused only in specific states of Eastern Amazon (Fernandes et al., 2018). Therefore it is necessary to perform a more inclusive study concerning the occurrence/distribution of As in different Amazon agroecosystems in order to provide information for the local population about possible health issues involved in the 
use of soil and water resources for living, building and growing crops in this region.

To the best of our knowledge, no research data regarding the determination of soluble and available soil As in the Brazilian Amazon region have been published so far. This is relevant, as such information could support public policies for decision makers and help guide future research in these sites in order to provide a better planning for a sustainable use of land and natural resources by the local population, while ensuring also human health and food security.

In this context, this study aims to: i) characterize and compare baseline levels of As in different sites in the Amazon region; ii) study the dynamics of extractable As fractions (soluble and available fractions) with depth, i.e., in three different layers (0-20, 20-40 and 40-60 cm) of soils occurring in agroecosystems with Brazil nuts plantations; and, iii) assess the influence of the main soil physicochemical attributes for determining the soil As concentrations and the occurrence of each arsenic fraction in the soils.

\section{Materials and methods}

\subsection{Study approach}

This study involved the following steps: (a) soil survey to collect baseline data for As in 9 target sites; (b) description of the natural variation of As and soil physicochemical attributes in each site; and, (c) correlation and PCA analysis to support inference of soil environmental controls for As variability in the soil. The methods used to reach our goals are described in the following sections.

\subsection{Sampling sites and characterization of the study area}

Soil samples were collected in nine sites belonging to the Amazon Biome in Brazil. Each site correspond to a Brazil nut stand, identified by: SM (Sena Madureira, state of Acre); XP (Xapuri, state of Acre); ANO (Anori, state of Amazonas); AR (Aruanã farm-Itacoatiara, state of Amazonas); AP (Laranjal do Jari, state of Amapá); MT (Itaúba, state of Mato Grosso); PA (Santarém, state of Pará); RO (Porto Velho, state of Rondônia) and RR (Caracaraí, state of Roraima). In each site, samples of 15 collection points were sampled in the native Amazon rainforest, except for AR (Itacoatiara), where samples of 18 points were collected in the Aruanã farm, which is a large Brazil nuts plantation. Samples were collected between 2014 and 2017. The chosen target sites for this study were the same ones used by Silva Junior et al. (2017) in their survey assessing the natural variation of selenium in Brazil nuts and soils from the Amazon region, to which we have added four additional areas. Sampling sites and detailed geographic information are provided in Fig. 1 and Table S1.

Soil samples were collected at the depths of $0-20,20-40$, and $40-60 \mathrm{~cm}$ at a distance of $3 \mathrm{~m}$ from the trunk of selected Brazil nuts trees. These samples were collected at four points and mixed to compose a single sample for each depth. The sampling method is represented schematically according to Silva Junior et al. (2017).









sources Observation and Science (EROS). 


\subsection{Soil physicochemical characterization}

Soil samples were taken to the Soil Science Department of the Federal University of Lavras, Minas Gerais-Brazil, where they were grinded, sieved at $<2 \mathrm{~mm}$, dried at room temperature, and subjected to chemical and physical (texture) analysis. The soil $\mathrm{pH}$ was determined potentiometrically in water $\left(\mathrm{pH} \mathrm{H}_{2} \mathrm{O}\right)$ and $\mathrm{KCl}\left(1 \mathrm{~mol} \mathrm{~L}^{-1}\right)$ in the ratio 1:2.5 soil/solution. The exchangeable cations $\left(\mathrm{Ca}^{2+}, \mathrm{Mg}^{2+}\right.$ and $\left.\mathrm{Al}^{3+}\right)$ were obtained by $1 \mathrm{~mol} \mathrm{~L}^{-1} \mathrm{KCl}$ extractant. Sulfur $\left(\mathrm{S}_{-} \mathrm{SO}_{4}^{2-}\right.$ ) was extracted as sulfate by monocalcium phosphate with acetic acid and the result converted to S. Available P, Na, K, and micronutrients (Fe, Zn, Mn, and $\mathrm{Cu})$ were obtained by Mehlich- $1\left(0.05 \mathrm{~mol} \mathrm{~L}^{-1} \mathrm{HCl}+0.0125 \mathrm{~mol} \mathrm{~L}^{-1}\right.$ $\mathrm{H}_{2} \mathrm{SO}_{4}$; in ratio $1: 10$ soil/solution). Potential acidity $(\mathrm{H}+\mathrm{Al})$ was estimated indirectly through SMP pH (Shoemaker et al., 1961). Exchangeable aluminum $\left(\mathrm{Al}^{3+}\right)$ was determined by titration with sodium hydroxide $\left(0.025 \mathrm{~mol} \mathrm{~L}^{-1} \mathrm{NaOH}\right)$. P was determined colorimetrically, $\mathrm{K}$ by flame emission photometry, $\mathrm{S}^{-\mathrm{SO}_{4}^{2-}}$ by turbidimetry, and $\mathrm{Ca}, \mathrm{Mg}$, $\mathrm{Zn}, \mathrm{Fe}, \mathrm{Mn}$, and $\mathrm{Cu}$ were determined by atomic absorption spectrometry (AAS) (Raij and Quaggio, 1983). The organic matter content was determined by oxidation of the organic matter in the soil with a potassium dichromate solution in the presence of sulfuric acid (Carter and Gregorich, 2006). Sum of bases (SB), cation exchange capacity at pH 7 (T), effective cation exchange capacity ( $\mathrm{t}$ ), base saturation (V\%), and aluminum saturation $(\mathrm{m})$ were calculated based on the results of the chemical analysis. The particle size analysis (clay, silt, and sand) was performed by the "Bouyoucos" method, as described by Embrapa (1997).

\subsection{Total arsenic determination}

Total As analyses was performed in air-dried and $<2 \mathrm{~mm}$ sieved soil samples. A portion of each soil sample was finely grinded $(<0.45 \mathrm{~mm})$ using an agate ball mill (Retch PM 400 mill). Soil samples ( $\sim 2.2 \mathrm{~g} \mathrm{DW})$ were fully digested in $70 \% \mathrm{HF}, 70 \% \mathrm{HNO}_{3}$ and $60 \% \mathrm{HClO}_{4}$ (TAG; Fisher Scientific UK Ltd), using perfluoroalkoxy (PFA) digestion vessels and a 48-place teflon-coated graphite digester block (Model A3, Analysco Ltd., Chipping Norton, UK) (Chilimba et al., 2011).

The digester block runs with two different programs, a mix of reagents and a few steps for 3 days as can be observed with further details in Table 1. After the digestion, the block was turned off and the tubes were left to cool down completely for about $30 \mathrm{~min}$. Digested samples were diluted to $50 \mathrm{~mL}$ into volumetric flasks using Milli-Q water and stored in $5 \% \mathrm{HNO}_{3}$ at room temperature in universal sample bottles, pending elemental analysis. Before the analysis in the ICP-MS, the extracts were diluted using $1 \mathrm{~mL}+9 \mathrm{~mL}$ of Milli-Q water.

Each digestion batch $(\mathrm{n}=70)$ included a standard reference material $(\mathrm{n}=3$ ) (NIST 2711a; Montana Soil II, National Institute of Standards and Technology, Gaithersburg, MD, USA), which contains $107 \pm$ $5 \mathrm{mg} \mathrm{kg}^{-1}$ As. The average recovery in the standard reference material was $101 \%(\mathrm{n}=21, \mathrm{SD}=6.61)$ for As. In addition, 3 blank samples were used in each batch for quality control purposes and for calculating limits of detection. The limit of detection (LOD) was established using 21 blank extracts for soil samples following the overall procedure. The values were calculated with three times the standard deviation (SD)

Table 1

HF digestion steps with digester block.

\begin{tabular}{|c|c|c|c|c|}
\hline Day & Program & Reagent & Volume (mL) & Steps \\
\hline \multirow{2}{*}{$1^{\circ}$} & \multirow{2}{*}{$1^{\mathrm{a}}$} & $\mathrm{HNO}_{3}$ & 2 & \multirow{5}{*}{$\begin{array}{l}\text { 1) } 80{ }^{\circ} \mathrm{C}, 8 \mathrm{~h} \text {; } \\
\text { 2) } 100{ }^{\circ} \mathrm{C}, 2 \mathrm{~h} \text {. } \\
\text { 1) } 120^{\circ} \mathrm{C}, 1 \mathrm{~h} \text {; } \\
\text { 2) } 140{ }^{\circ} \mathrm{C}, 3 \mathrm{~h} \text {; } \\
\text { 3) } 160{ }^{\circ} \mathrm{C}, 4 \mathrm{~h} \text {; } \\
\text { 4) } 50{ }^{\circ} \mathrm{C}, 1 \mathrm{~h} .\end{array}$} \\
\hline & & $\mathrm{HClO}_{4}$ & 1 & \\
\hline $2^{\circ}$ & 2 & $\mathrm{HF}$ & 2.5 & \\
\hline \multirow{2}{*}{$3^{\circ}$} & \multirow{2}{*}{ - } & $\mathrm{HNO}_{3}$ & 2.5 & \\
\hline & & Mili-Q $\mathrm{H}_{2} \mathrm{O}$ & 2.5 & \\
\hline
\end{tabular}

a Left overnight with the program turned on. of the blanks used in each batch $(\mathrm{n}=3)$ using the formula: SD (3 blanks) $\times 3 \times$ final volume extract $(\mathrm{mL}) \div$ sample weight $(\mathrm{g})$. The average LOD was $0.029 \mathrm{mg} \mathrm{kg}^{-1}$ for total soil As.

\subsection{Soluble and available As in soil (extractable As)}

Soluble and available As analyses were performed in sequence, according to the modified method described by Cai et al. (2002). First, for the soluble fraction, $2 \mathrm{~g}$ of air-dried and $<2 \mathrm{~mm}$ sieved soil was added into a $50 \mathrm{~mL}$ polycarbonate centrifuge tube. Next $10 \mathrm{~mL}$ of $0.01 \mathrm{~mol} \mathrm{~L}^{-1} \mathrm{KNO}_{3}$ was added to each tube and the suspensions were shaken for $2 \mathrm{~h}$ using a rotary shaker $(20 \mathrm{rpm})$. Soil suspensions were then centrifuged for $30 \mathrm{~min}$ at $3500 \mathrm{rpm}$, filtered to $<0.22 \mu \mathrm{m}$ using a Millex syringe driven filter unit (Millipore, Cork, Ireland) and stored at room temperature prior to analysis of As by ICP-MS. In the second step, for the available fraction, an extraction with $10 \mathrm{~mL}$ of $0.016 \mathrm{M}$ $\mathrm{KH}_{2} \mathrm{PO}_{4}$ was performed in the same tubes from the previous step. The suspensions were shaken for $1 \mathrm{~h}$ in the rotary shaker $(20 \mathrm{rpm})$ and then centrifuged for $30 \mathrm{~min}$ at $3500 \mathrm{rpm}$. The supernatant was filtered using $<0.22 \mu \mathrm{m}$ syringe filter and put in a universal tube (used for analysis in the ICP-MS). For the ICP-MS analysis, $4.8 \mathrm{~mL}$ of the supernatant collected from $\mathrm{KNO}_{3}$ and $\mathrm{KH}_{2} \mathrm{PO}_{4}$ extractions were added into an ICP tube containing $0.2 \mathrm{~mL}$ of $50 \% \mathrm{HNO}_{3}$ for As analysis. The limits of detection (LOD) for soluble and available soil As were calculated as previously mentioned, and corresponded to 0.047 and $0.056 \mu \mathrm{gg}^{-1}$, respectively.

\subsection{Analytical determination of As}

The analytical determinations of As were performed using Inductively Coupled Plasma-Mass Spectrometry (ICP-MS, X-Series II, Thermo Fisher Scientific) in the Environmental geochemistry analytical suite from the University of Nottingham-UK. Samples were introduced

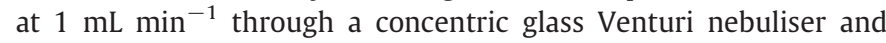
Peltier-cooled $\left(3^{\circ} \mathrm{C}\right)$ spray chamber. Instrumental drift was corrected using internal standards $\left({ }^{72} \mathrm{Ge},{ }^{103} \mathrm{Rh}\right.$ and $\left.{ }^{185} \mathrm{Re}\right)$. Data for total As concentration in soils are reported on a dry weight basis (DW) and expressed in $\mathrm{mg} \mathrm{kg}^{-1}$. Data for soluble and available As are expressed in $\mu \mathrm{g} \mathrm{kg}^{-1}$.

\subsection{Statistical analysis}

A descriptive analysis of the concentrations of total As, as well as for soluble and available As was carried out using Box plots in order to display data distribution. The data were subjected to Pearson's correlation analysis, which was performed between total, soluble and available As concentrations and other physicochemical soil properties. All the graphics were performed using the software R 3.4.4 (R Development Core Team, 2018).

Analysis of variance was performed to assess how the logtransformed As concentration in soils varied across different sites. After verifying the significance through ANOVA, the mean values for As concentration were compared among sites for the three layers studied using Tukey's HSD test with the package emmeans v 2.23 (Lenth, 2016) in R 3.4.4 (R Development Core Team, 2018). The same approach was used to compare soluble and available As in soils, but in this case using generalized least squares (GLS) for the data log-transformed, in order to allow the variance to be estimated separately for each site (Cleasby and Nakagawa, 2011).

A principal component analysis (PCA) was performed to find out the main soil attributes influencing As concentration in the soil according to the degree of variance explained and to confirm the previous relationships obtained by Pearson correlation analyses. Because the distribution of As concentrations and fractions was not normal, the data were logtransformed, before analysis to meet the assumption of normality required for the Pearson correlation and PCA, except for soil pH, because it follows a normal distribution in soil data. 


\section{Results and discussion}

\subsection{Soil physicochemical properties, element contents and associations}

The chemical and textural attributes of soil varied widely among the sites studied, reflecting a great variability in soil characteristics throughout the Amazon basin that may be related to diversity of parent material and soil types. Most of collected samples show acidic soils (mean pH ranging from 3.75 to 5.5) which in fact reflects the well-known weathered soils from this region according to Alvarez et al. (1999). The OM content in the topsoil is classified as moderate in most sites (average OM content ranging from $1.16 \%$ to $2.63 \%$ ) according to Alvarez et al. (1999) (Table 2). The moderate contents of OM can be explained by the high temperature and precipitation levels (humidity) in the region, i.e., the most important climatic factors controlling the dynamic of ecological processes (Da Silva et al., 2018), which reflects not only in the biomass production but also in decomposition rates of the litter in the soil.

The dominant soil texture was clay (AR, RO and PA) and sandy loam (MT and AP). Such high percentage of clay content facilitates As retention, especially onto kaolinite, as well as $\mathrm{Fe}$ and $\mathrm{Al}$ oxyhydroxide surfaces that predominate in the clay fraction of the highly developed soils of the Amazon region, which is subjected to strong weathering conditions (De Souza et al., 2018) (Table 2).

Soil cation exchange capacity (CEC) ranged from 2.96 to $25.2 \mathrm{cmol}_{\mathrm{c}}$ $\mathrm{dm}^{-3}$ demonstrating a great variability among the sites studied. The soils from ANO showed the highest mean values of CEC $\left(22.6 \mathrm{cmol}_{\mathrm{c}}\right.$ $\mathrm{dm}^{-3}$ ). For the others sampled sites, CEC values were all below 13 $\mathrm{cmol}_{\mathrm{c}} \mathrm{dm}^{-3}$ with the lowest values observed in the sites RR and AP (5.33 and $4.28 \mathrm{cmol}_{\mathrm{C}} \mathrm{dm}^{-3}$, respectively). This wide variation in soil CEC indicates that besides the predominance of dystrophic and highly weathered soils with secondary minerals, there are still soils with 2:1 clay minerals, composing less weathered soils with high activity in the clay fraction in this region (Table 2).

Extractable $\mathrm{S}$ and $\mathrm{P}$ in the present study exhibited considerable variation among the sites with mean values ranging from 5.29 to $47.9 \mathrm{mg} \mathrm{kg}^{-1}(\mathrm{~S})$ and from 0.52 to $3.72 \mathrm{mg} \mathrm{kg}^{-1}(\mathrm{P})$. In general, the content of available P was moderate in most sites, where also the OM contents are usually higher than in deeper layers, except in the sites MT and RO in southern Amazon, which contained available P values below $2 \mathrm{mg} \mathrm{kg}^{-1}$ (Table 2). The content of extractable $S$ on the other hand presented higher values in the sites AR and RO (Table 2).

Iron ( $\mathrm{Fe}$ ) usually plays an important role in controlling the concentration of trace elements in soil solution because of its involvement in adsorption. The variation of available Fe among the sites was also quite outstanding with mean values ranging from $58.5 \mathrm{mg} \mathrm{kg}^{-1}$ (AP) to $489.7 \mathrm{mg} \mathrm{kg}^{-1}$ (ANO) (Table 2). We observed that soil $\mathrm{pH}$ is the major factor explaining the concentration of this element in soil solution, since the site with lowest Fe content presents also the highest $\mathrm{pH}$ (site AP). On the other hand, available Fe might not reflect the concentration of iron (hydr) oxides that explains the retention of anions in soil.

\subsection{Total As concentration in soil}

Total As concentrations ranged from 0.98 to $41.7 \mathrm{mg} \mathrm{kg}^{-1}$, with $75 \%$ of the soil samples showing values lower than $6.93 \mathrm{mg} \mathrm{kg}^{-1}$, which is close to the mean value of total As reported for different soils worldwide (i.e., $6.83 \mathrm{mg} \mathrm{kg}^{-1}$ ) (Kabata-Pendias, 2011). The sites with highest baseline As concentration were SM followed by RO and XP. On the other hand, the sites with lowest As concentrations were AP and RR, according to the Tukey HSD test (Fig. 2).

Interestingly, total As concentration in the western Amazon (SM, XP and $\mathrm{RO}$ ) presented the highest values and a wide variation not only among the layers but also within the three layers evaluated. The total As concentration in the western Amazon showed median concentrations increasing from the topsoil to the deepest layers as follow: SM $\left(15.9<19.0<26.5 \mathrm{mg} \mathrm{kg}^{-1}\right)$ and XP $\left(5.96<7.20<9.34 \mathrm{mg} \mathrm{kg}^{-1}\right)$ for the layers $0-20,20-40$ and $40-60 \mathrm{~cm}$, respectively. A wide variation for arsenic concentration within layers was observed especially at the deepest layer (40-60 cm), which also presented the highest As concentrations for each site studied in the western Amazon: SM (17.3 to $41.7 \mathrm{mg} \mathrm{kg}^{-1}$ ), XP (5.69 to $17.8 \mathrm{mg} \mathrm{kg}{ }^{-1}$ ), and $\mathrm{RO}$ (5.83 to $23.6 \mathrm{mg} \mathrm{kg}^{-1}$ ) (Fig. 2).

There is no nationwide As baseline level established by the Brazilian legislation to be used in terms of quality reference values (QRVs) for soils. This is also true for soils of the Brazilian Amazon region. However, a QRV for As in soils from the Eastern Amazon was proposed by Fernandes et al. (2018). These authors observed total As concentration ranging from 0.07 to $7.75 \mathrm{mg} \mathrm{kg}^{-1}$ in the $0-20 \mathrm{~cm}$ layer and, considering the 90th percentile of the sample population after eliminating anomalies (cumulative frequency distribution), $2.7 \mathrm{mg} \mathrm{kg}^{-1}$ was suggested as the QRV. Given the heterogeneity in the pedogeoclimatic conditions in the region, the 90th percentile seems to best represent the QRVs because of the wide variances for the values observed, as suggested by Conama (2009).

In the present study $57 \%$ of the samples from the $0-20 \mathrm{~cm}$ soil layer show As concentrations higher than the QRV for the 90th percentile proposed by Fernandes et al. (2018), which reinforces the difficulty of establishing a single QRV for a very large region as the Brazilian Amazon. In addition, the medians for total As concentrations in the three layers $(0-20,20-40$ and $40-60 \mathrm{~cm})$ from the site SM are higher than the As prevention level ( $15 \mathrm{mg} \mathrm{kg}^{-1}$ ) established by the Brazilian Normative CONAMA 420, for soils nationwide (Conama, 2009) (Fig. 2). This is indicative that the current Brazilian prevention values need to be validated using representative soils from the Amazon basin since this

Table 2

Physicochemical properties of the topsoil $(0-20 \mathrm{~cm})$ from samples collected at different sites in the Amazon region.

\begin{tabular}{|c|c|c|c|c|c|c|c|c|c|c|}
\hline \multirow[t]{2}{*}{ Site } & \multirow[t]{2}{*}{$\mathrm{n}$} & \multirow[t]{2}{*}{$\mathrm{pH}\left(\mathrm{H}_{2} \mathrm{O}\right)$} & \multirow[t]{2}{*}{ OM (\%) } & \multirow{2}{*}{$\begin{array}{l}\mathrm{CEC} \\
\left(\mathrm{cmol}_{\mathrm{c}} \mathrm{dm}^{-3}\right)\end{array}$} & \multirow{2}{*}{$\begin{array}{l}\mathrm{S} \\
\left(\mathrm{mg} \mathrm{kg}^{-1}\right)\end{array}$} & \multirow[t]{2}{*}{$\mathrm{P}\left(\mathrm{mg} \mathrm{kg}^{-1}\right)$} & \multirow{2}{*}{$\begin{array}{l}\mathrm{Fe} \\
\left(\mathrm{mg} \mathrm{kg}^{-1}\right)\end{array}$} & Clay & Silt & Sand \\
\hline & & & & & & & & \multicolumn{3}{|l|}{$(\%)$} \\
\hline SM & 15 & $4.53 \pm 0.34$ & $1.42 \pm 0.35$ & $6.92 \pm 1.74$ & $5.29 \pm 1.17$ & $3.72 \pm 1.27$ & $174.9 \pm 86.3$ & $21.6 \pm 4.70$ & $22.5 \pm 2.38$ & $55.9 \pm 4.85$ \\
\hline $\mathrm{XP}$ & 15 & $4.36 \pm 0.32$ & $1.62 \pm 0.55$ & $7.21 \pm 2.25$ & $8.09 \pm 5.16$ & $3.08 \pm 0.75$ & $190.1 \pm 83.9$ & $18.4 \pm 5.37$ & $32.3 \pm 10.2$ & $49.3 \pm 10.5$ \\
\hline MT & 15 & $4.19 \pm 0.16$ & $2.32 \pm 0.40$ & $7.10 \pm 2.52$ & $7.32 \pm 2.00$ & $1.46 \pm 0.32$ & $324.3 \pm 69.6$ & $19.5 \pm 2.61$ & $3.86 \pm 1.85$ & $76.6 \pm 2.82$ \\
\hline AR & 18 & $4.26 \pm 0.09$ & $2.63 \pm 0.32$ & $7.97 \pm 1.34$ & $16.5 \pm 7.06$ & $2.56 \pm 0.61$ & $183.0 \pm 48.6$ & $77.6 \pm 3.46$ & $10.1 \pm 2.37$ & $12.3 \pm 2.56$ \\
\hline ANO & 15 & $4.00 \pm 0.35$ & $2.03 \pm 0.70$ & $22.6 \pm 10.9$ & $9.55 \pm 4.97$ & $2.53 \pm 0.85$ & $489.7 \pm 134.1$ & $27.2 \pm 5.82$ & $56.7 \pm 8.05$ & $16.1 \pm 11.9$ \\
\hline $\mathrm{AP}$ & 15 & $5.49 \pm 0.34$ & $1.16 \pm 0.34$ & $4.28 \pm 0.67$ & $9.49 \pm 1.60$ & $2.25 \pm 0.72$ & $58.5 \pm 22.6$ & $19.9 \pm 2.60$ & $3.40 \pm 1.92$ & $76.7 \pm 3.24$ \\
\hline RR & 15 & $4.46 \pm 0.16$ & $2.43 \pm 0.46$ & $5.33 \pm 0.73$ & $10.1 \pm 1.64$ & $2.38 \pm 0.28$ & $177.2 \pm 50.2$ & $44.1 \pm 5.97$ & $8.13 \pm 3.54$ & $47.7 \pm 6.12$ \\
\hline RO & 15 & $3.75 \pm 0.22$ & $2.40 \pm 0.37$ & $12.6 \pm 3.63$ & $18.0 \pm 8.88$ & $1.87 \pm 0.37$ & $196.2 \pm 70.8$ & $51.7 \pm 9.78$ & $28.1 \pm 12.5$ & $20.2 \pm 7.70$ \\
\hline $\mathrm{PA}^{\mathrm{a}}$ & 15 & $4.41 \pm 0.26$ & $2.20 \pm 0.42$ & $9.24 \pm 2.24$ & $10.6 \pm 3.51$ & $2.25 \pm 0.43$ & $242.4 \pm 62.5$ & 52.0 & 8.0 & 40.0 \\
\hline
\end{tabular}

Values of soil physicochemical attributes are mean \pm standard deviation (SD).


Jari, state of Amapá); MT (Itaúba, state of Mato grosso); PA (Santarém, state of Pará); RO (Porto Velho, state of Rondônia) and RR (Caracaraí, state of Roraima).

a Texture in PA was derived from one single analysis performed by a composite sample resulted of subsamples from 5 spots in the site. 









of Tukey's HSD test $(\mathrm{p}=0.05)$ on the log-transformed As concentration, following a significant ANOVA $(\mathrm{p}<0.001)$.

region may present soils that may be naturally enriched with As. All other studied sites presented median As concentrations below $6 \mathrm{mg} \mathrm{kg}-1$ - a value close to the average As content reported by Campos et al. (2007) for 17 Brazilian oxisols (i.e., $5.92 \mathrm{mg} \mathrm{kg}^{-1}$ ) with the lowest median concentrations observed in the site AP (1.30, 1.53 and $1.71 \mathrm{mg} \mathrm{kg}^{-1}$ for $0-20,20-40$ and $40-60 \mathrm{~cm}$ respectively) (Fig. 2).

The sites from the central and eastern portion of the Amazon basin (ANO, AR, PA and AP) presented low As concentrations in all the three layers evaluated. They also presented low variation among and within the layers, as observed in the medians concentrations in the site AR (5.07, 5.33 and $5.41 \mathrm{mg} \mathrm{kg}^{-1}$ for $0-20,20-40$ and $40-60 \mathrm{~cm}$ respectively) (Fig. 2).

The sites located in the northern and southern portion of the Amazon, which are RR (medians of $1.39,1.70$ and $1.80 \mathrm{mg} \mathrm{kg}^{-1}$ ) and MT (medians of 2.56, 2.99 and $3.03 \mathrm{mg} \mathrm{kg}^{-1}$ ) also presented low total As concentration for the three layers evaluated compared to the other sites studied, and no meaningful variation among and within the layers was noticed (Fig. 2).

Campos et al. (2013b) determined background levels of As in representative soils from the states of Goiás and Minas Gerais (from 2000 to $2500 \mathrm{~km}$ far away from the studied sites), which belongs to Cerrado biome (Brazil) in three sub-regions and observed concentrations similar to those found in the southern Amazon in the present study, with mean concentrations in a decreasing order as follow: East of state of Goiás (3.29 $\mathrm{mg} \mathrm{kg}^{-1}$ ) > Triângulo Mineiro (state of Minas Gerais) (2.18 $\left.\mathrm{mg} \mathrm{kg}^{-1}\right)>$ Northeast of Minas Gerais $\left(0.62 \mathrm{mg} \mathrm{kg}^{-1}\right)$. The highest As concentrations were observed in profiles of plintosols and cambisols from the East of Goiás. In another study, Campos et al. (2013a) observed levels of As ranging between $0.14 \mathrm{mg} \mathrm{kg}^{-1}$ (for a gley soil) and $9.3 \mathrm{mg} \mathrm{kg}^{-1}$ (for an oxisol) in soils from Minas Gerais. Those concentrations are usually found in non-contaminated soils ( $<10 \mathrm{mg} \mathrm{kg}{ }^{-1}$ ) (Adriano, 2001; Campos et al., 2007, 2013a; Bundschuh et al., 2012) and are similar to the ones reported in the present study.

In a different scenario far away from the Amazon region, in the Iron Quadrangle, southeast region of Brazil, within the state of Minas Gerais, the presence of As is associated with primary gold deposits where it is contained predominantly in S-bearing minerals such as arsenopyrite and pyrite (Borba et al., 2003). Also in the iron quadrangle, Alves and Rietzler (2015) observed high As concentrations in soils from mining areas in Nova Lima (13.2 in the control site and $489 \mathrm{mg} \mathrm{kg}^{-1}$ in the mine stream) and Santa Bárbara (82.3 in the control site and $1329 \mathrm{mg} \mathrm{kg}^{-1}$ nearby the mine plant). Out of the Iron Quadrangle, but still in Minas Gerais, natural soil As concentrations found in a private 
natural reserve (native Cerrado vegetation) located nearby a goldmining area ranged from 25 to $35 \mathrm{mg} \mathrm{kg}^{-1}$ (Ono et al., 2012), which is also greater than the prevention level established by Normative 420 , for Brazilian soils (Conama, 2009). These studies emphasize the importance of the parent material in total arsenic concentration in soils and make us believe that the main source of arsenic, in the present study, is geogenic.

\subsection{Extractable soil As (soluble and available)}

Extractions for soluble and available As showed the highest concentrations for the site SM which is in accordance with the results observed for total As. For the soluble fraction the concentrations ranged from $<0.047$ (MT) to $16 \mu \mathrm{kg}^{-1}$ (SM). Available As varied from 2.14 (AR) to $236.5 \mu \mathrm{gg}^{-1}$ (SM) (Fig. 3).

Observing the mean concentrations for soluble As, it is noteworthy that in SM the values are increasing from the topsoil to the deepest layers. On the other hand, in the sites AR, ANO, PA, RO and AP, soluble As decreases from the topsoil $(0-20 \mathrm{~cm})$ to the deepest layers $(20-40$ and $40-60 \mathrm{~cm})$. The sites RR and AP presented the lowest average concentration for soluble As (Fig. 3). The site with highest $\mathrm{pH}$ (AP) also presented the lowest median values for soluble As (Fig. 3). This effect is confirmed by the negative correlation between soluble As and $\mathrm{pH}$ in all the three layers studied (Table 3).

The average concentration for available As in SM in the layers $0-20,20-40$ and $40-60 \mathrm{~cm}\left(45.3,68.6\right.$ and $\left.117 \mu \mathrm{g} \mathrm{kg}^{-1}\right)$ are at least 4-fold higher than those observed in all other sites studied. There was no meaningful variation among the sites for available As.

The observed behavior of soluble and available As in these soils may be partly explained by their interactions with available P (Table 2), which showed positive correlation with both fractions in all the three layers studied (Table 3 ). This is expected as a greater content of $\mathrm{P}$ in oxidic soils (which retain phosphate strongly) make As much more available and soluble due to competitive adsorption on positively-charged sites (Campos et al., 2013a).

Considering the proportional contribution given by each fraction (soluble and available) to the extractable As concentration, it is noticeable that available As represents the major fraction with $>70 \%$ of the As being extracted by $\mathrm{KH}_{2} \mathrm{PO}_{4}$ on average in all the sites studied.
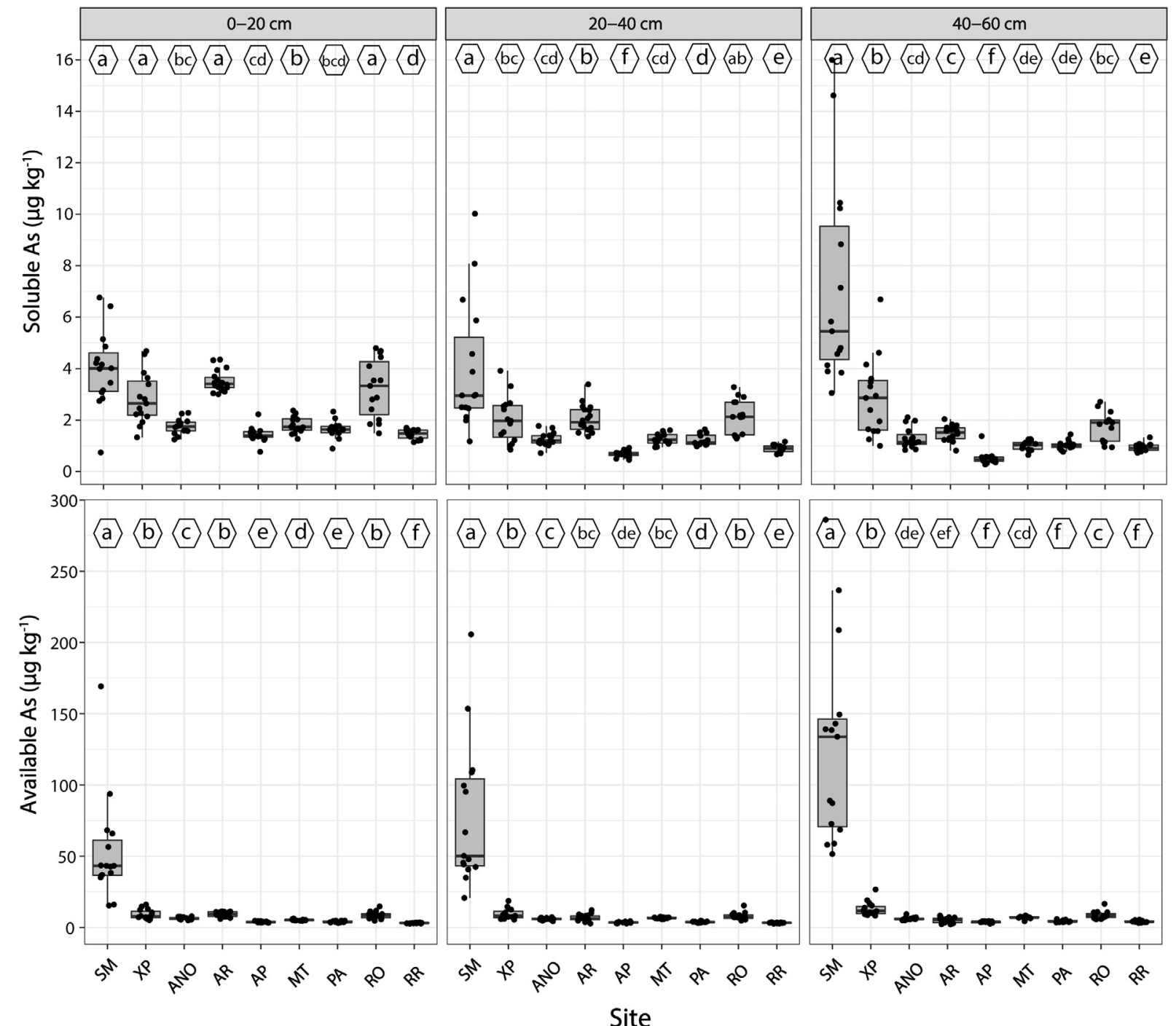

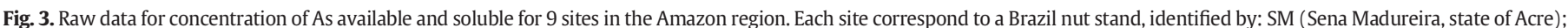

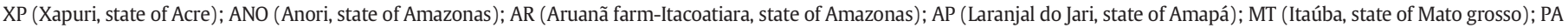

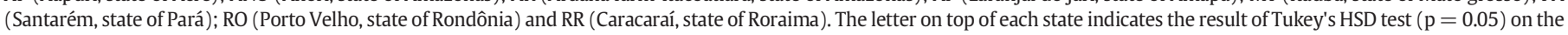
log-transformed As concentration, following a significant ANOVA $(p<0.001)$ using generalized least squares. 
Table 3

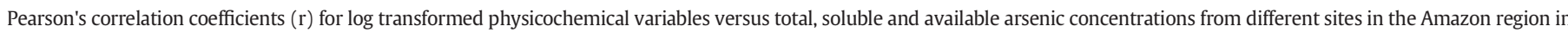
the layers $0-20 \mathrm{~cm}, 20-40$ and $40-60 \mathrm{~cm}$.

\begin{tabular}{|c|c|c|c|c|c|c|c|c|c|}
\hline \multirow[t]{2}{*}{ Soil attribute } & \multicolumn{3}{|l|}{$0-20 \mathrm{~cm}$} & \multicolumn{3}{|c|}{$20-40 \mathrm{~cm}$} & \multicolumn{3}{|l|}{$40-60 \mathrm{~cm}$} \\
\hline & As & As- $\mathrm{KNO}_{3}$ & As- $\mathrm{KH}_{2} \mathrm{PO}_{4}$ & As & As- $\mathrm{KNO}_{3}$ & As- $\mathrm{KH}_{2} \mathrm{PO}_{4}$ & As & As- $\mathrm{KNO}_{3}$ & As- $\mathrm{KH}_{2} \mathrm{PO}_{4}$ \\
\hline $\mathrm{pH}$ & $-0.43^{* *}$ & $-0.33^{* *}$ & -0.14 & $-0.44^{* *}$ & $-0.48^{* *}$ & $-0.17^{*}$ & $-0.46^{* *}$ & $-0.36^{* *}$ & -0.17 \\
\hline $\mathrm{OM}$ & 0.06 & $0.27^{* *}$ & -0.12 & -0.02 & 0.11 & $-0.19^{*}$ & -0.12 & -0.15 & $-0.23^{* *}$ \\
\hline CEC & $0.34^{* *}$ & $0.26^{* *}$ & 0.15 & $0.33^{* *}$ & $0.35^{* *}$ & $0.22^{*}$ & $0.39^{* *}$ & $0.39^{* *}$ & $0.30^{* *}$ \\
\hline $\mathrm{P}$ & $0.27^{* *}$ & $0.39^{* *}$ & $0.43^{* *}$ & $0.31^{* *}$ & $0.25^{* *}$ & $0.32^{* *}$ & $0.29^{* *}$ & $0.23^{* *}$ & $0.31^{* *}$ \\
\hline $\mathrm{S}$ & 0.03 & 0.08 & $-0.23^{*}$ & 0.14 & 0.10 & -0.14 & 0.06 & -0.05 & $-0.19^{*}$ \\
\hline $\mathrm{Al}$ & $0.53^{* *}$ & $0.40^{* *}$ & $0.41^{* *}$ & $0.52^{* *}$ & $0.55^{* *}$ & $0.44^{* *}$ & $0.56^{* *}$ & $0.60^{* *}$ & $0.47^{* *}$ \\
\hline $\mathrm{Fe}$ & 0.08 & 0.09 & -0.01 & -0.06 & 0.09 & -0.15 & -0.15 & $-0.19^{*}$ & $-0.29^{* *}$ \\
\hline Clay & 0.15 & $0.26^{* *}$ & -0.06 & 0.04 & 0.10 & $-0.21^{*}$ & 0.01 & 0.0 & $-0.29^{* *}$ \\
\hline Silt & $0.55^{* *}$ & $0.31^{* *}$ & $0.40^{* *}$ & $0.57^{* *}$ & $0.45^{* *}$ & $0.37^{* *}$ & $0.56^{* *}$ & $0.51^{* *}$ & $0.40^{* *}$ \\
\hline
\end{tabular}

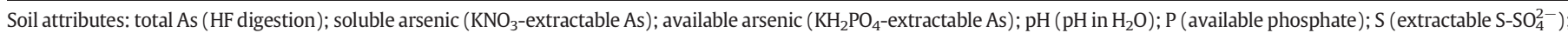
CEC (cation exchange capacity); OM (organic matter); Al (exchangeable aluminum); Fe (available iron); clay and silt (\%).

* Significant correlation $(\mathrm{p}<0.05)$.

** Significant correlation $(\mathrm{p}<0.01)$. The correlation includes all the sites studied except the site "Santarém/PA" because the data for texture was obtained in only one point.

Generally, the contribution given by the soluble fraction in all the sites reduces from the topsoil to the deepest layer, as follows: $25 \%>18 \%$ $>16 \%$ (0-20, 20-40 and 40-60 cm respectively) (Fig. 4). The site with the greatest contribution given by available As was SM with $92 \%, 94 \%$ and $94 \%$ for the $0-20,20-40$ and $40-60$ soil layers. On the other hand, the sites with smallest contribution given by available As were RR in

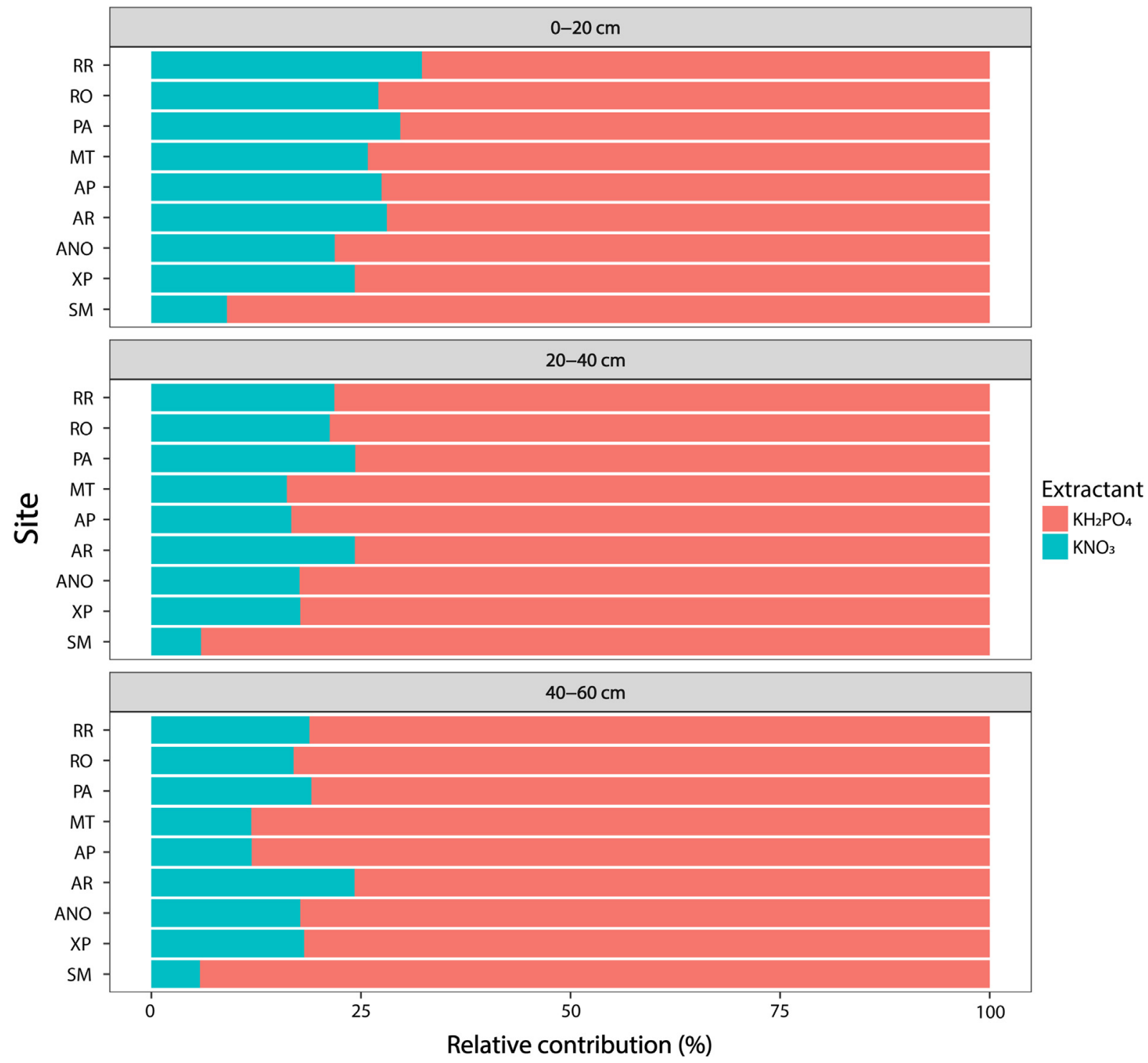

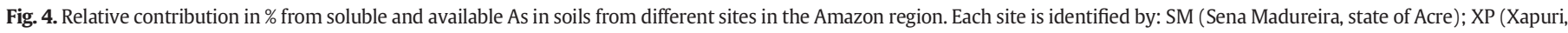

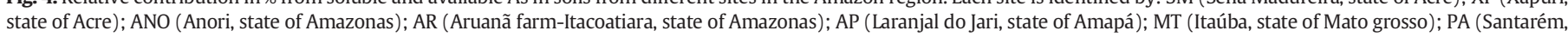
state of Pará); RO (Porto Velho, state of Rondônia) and RR (Caracaraí, state of Roraima). 
the layer 0-20 cm (67.7\%), PA in the layer $20-40 \mathrm{~cm}$ (75.7\%) and AR in the layer 40-60 cm (77.5\%) (Fig. 4).

Arsenic availability was also assessed using tri-distilled water, ammonium sulfate, ammonium phosphate, ammonium oxalate + oxalic acid, a mixture of organic acids, Mehlich-1, and USEPA 3051A in artificially contaminated soils (entisol and oxisol) by Melo et al. (2012). The extracting solutions tested in the experiment were equally efficient in assessing plant availability of As in the soils, however there was greater concentration of As extracted from the clayey entisol when compared with the medium-textured oxisol due to differences between the adsorptive capacities of these soils. Besides validating extractants for plant-available As, these authors emphasized the capacity of tropical soils, with variable charge, to adsorb As, especially those soils rich in clay (Melo et al., 2012).

\subsection{Relationship between soil As and physicochemical attributes}

Total As concentration (total As) correlated positively ( $\mathrm{p}<0.05$ ) with $\mathrm{CEC}$, available $\mathrm{P}, \mathrm{K}$, exchangeable $\mathrm{Al}$, and silt in the three layers studied and also with available $\mathrm{Zn}$ in the $20-40$ and $40-60 \mathrm{~cm}$ layers. Total As correlated negatively $(\mathrm{p}<0.05$ ) with $\mathrm{pH}$, exchangeable $\mathrm{Ca}$, available $\mathrm{Cu}$ in the three layers studied and also with exchangeable $\mathrm{Mg}$ and available $\mathrm{Mn}$ in the $0-20 \mathrm{~cm}$ layer and with available $\mathrm{B}$ and sand in the $0-20$ and $20-40 \mathrm{~cm}$ layers. These results indicates that, in tropical soil conditions, increasing $\mathrm{pH}$ values will decrease total As content either directly because of its influence on colloidal charges (i.e., causing a decrease in positive charges) or indirectly influencing the availability and retention of competing anions such as phosphate and sulfate (considering that soils are open systems and available forms can be removed, thereby reducing total levels) (Table 3).

Soluble As correlated positively ( $\mathrm{p}<0.05$ ) with CEC, available $\mathrm{P}$, exchangeable $\mathrm{Al}$ and silt in the three layers evaluated and also with $\mathrm{OM}$ and clay in the $0-20 \mathrm{~cm}$ layer and with available $\mathrm{Zn}$ and $\mathrm{K}$ in the
40-60 cm layer. Soluble As correlated negatively $(\mathrm{p}<0.05)$ with $\mathrm{pH}$, exchangeable $\mathrm{Ca}$ and available $\mathrm{Cu}$ in the three layers studied and also with exchangeable $\mathrm{Mg}$, available $\mathrm{B}$ and sand in the $0-20$ and $20-40 \mathrm{~cm}$ layers following by $\mathrm{Fe}$ in the $40-60 \mathrm{~cm}$ and available $\mathrm{Mn}$ in the $0-20$ and 40-60 cm layers (Table 3 ).

On the other hand, available As correlated positively $(\mathrm{p}<0.05)$ with available $\mathrm{P}, \mathrm{K}, \mathrm{Zn}$, exchangeable $\mathrm{Al}$ and silt in all the three layers studied and also with CEC in the 20-40 and 40-60 cm layers and with available $\mathrm{Mn}$ in the $20-40 \mathrm{~cm}$ layer following by sand in the $40-60 \mathrm{~cm}$ layer. Available As correlated negatively $(\mathrm{p}<0.05)$ with $\mathrm{OM}$ and clay in the 20-40 and 40-60 cm, and also with $\mathrm{pH}$ in the $20-40 \mathrm{~cm}$, with extractable $S$ in the $0-20$ and 40-60 cm layers, Fe in the 40-60 cm layer and available $\mathrm{Cu}$ in the $0-20 \mathrm{~cm}$ layer (Table 3 ).

In the present study, an important factor influencing As bioavailability that negatively affected total and soluble As was soil $\mathrm{pH}$ as can be observed in the Fig. 5. As pointed out by Zhang et al. (2017), numerous studies have shown that soil $\mathrm{pH}$ is an important factor controlling arsenic geochemistry, with adsorption of As decreasing as $\mathrm{pH}$ increases. This is attributed to the higher amounts of negative charges on soil components that generate variable charge, such as 1:1 clays, along with less amounts of positive charges on $\mathrm{Fe}$ and $\mathrm{Al}$ oxides. Such $\mathrm{pH}$ influence on charge generation is pronounced in tropical soils, since these are variable charge soils (Fontes et al., 2001).

According to Huang et al. (2006), $\mathrm{NaH}_{2} \mathrm{PO}_{4}$-extractable As correlates well with total As concentrations found in edible parts of various crops and soils collected from paddy rice fields in suburban areas of Fukan province in southeast China, showing the usefulness of this extractant to assess the bioavailability of As in soils. These authors also reported that As availability decreased significantly with increasing silt size $(0.02-0.002 \mathrm{~mm})$ and free iron content, but increased significantly with soil $\mathrm{pH}$ and organic matter content. Those findings are not supported by results observed in the present study for the silt fraction, which showed positive correlation with

\section{Arsenic availability in tropical soils}

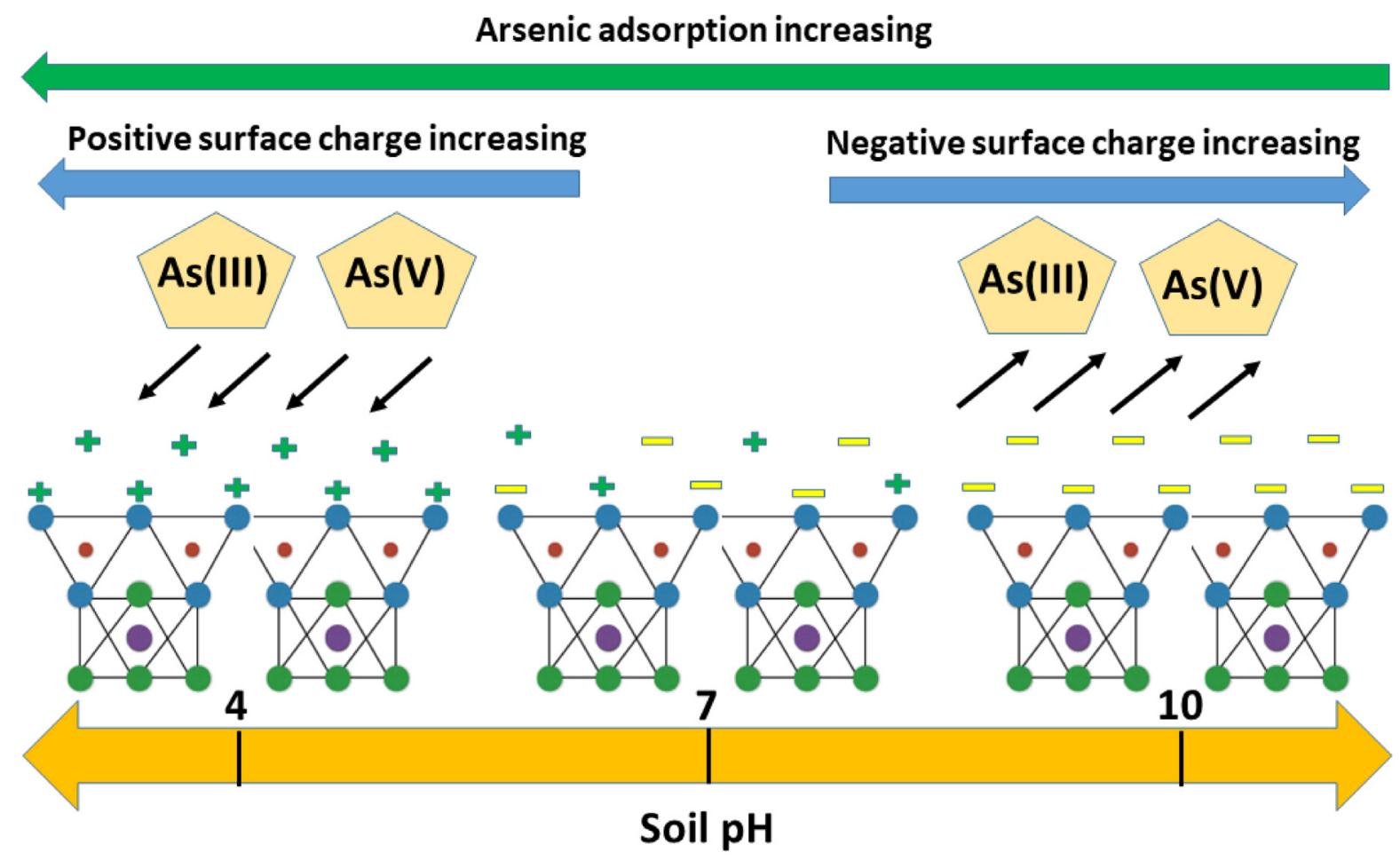

Fig. 5. Major mechanism at the soil colloid-soil solution interface controlling arsenic availability in tropical soils. 
total, soluble, and available As in soil samples for all the three layers studied (Table 3).

Similarly to what was observed in the present study (20-40 and 40-60 cm layers), Melo et al. (2012) observed that As availability (expressed by concentration of As in plants) was negatively correlated with clay content. The main reason for finding negative correlations between available As and clay content, especially in subsurface, is because of the particular composition and characteristics of the clay fraction in tropical soils, which presents significant amounts of Fe and Al oxides and oxyhydroxides as well as high ZPC (Fontes et al., 2001). According to McBride (1994), chemical adsorption of As occurs mainly in Fe and $\mathrm{Al}$ oxides, as well as in amorphous aluminosilicates, with small quantities being retained by clay silicates and organic substances. For this reason, the mobility and bioavailability of As is generally lower in clayey soils with variable charge.

It is noteworthy that the highest correlation coefficients were observed between exchangeable $\mathrm{Al}\left(\mathrm{Al}^{3+}\right)$ and total, available, and soluble As in all the three layers studied, which were all positive $(p<0.05)$ (Table 3). The mechanism by which high $\mathrm{Al}^{3+}$ is associated with high As concentrations may be related to the preferential retention of $\mathrm{Al}$ in the negative sites of variable-charge minerals (including clay minerals, Fe and $\mathrm{Al}$ oxides and oxyhydroxides), thus creating a bridge for binding As through formation of surface ternary complexes, which has been previously reported (Oliveira et al., 2015).

Given that As (as arsenate) and P (as phosphate) present similar chemical behavior in soils, available $\mathrm{P}$ has an antagonistic effect upon As retention, as P can compete with As for anionic sorption sites (Sharma et al., 2011). This explains the positive correlation observed between the soluble and available As fractions and the available P in soil samples of all the three layers studied (Table 3). Several studies show evidence supporting a strong relationship between As availability in soil and soil available $\mathrm{P}$ as a consequence of the chemical and structural similarities between their anionic forms (Punshon et al., 2017; ArcoLázaro et al., 2018; Chowdhury et al., 2018). Jiang et al. (2014) observed significant positive correlation between soil available $\mathrm{P}$ and exchangeable As. The authors also stated that the main factors influencing As uptake by rice in that study included soil $\mathrm{pH}$, total organic carbon, as well as soil available $\mathrm{P}$ and $\mathrm{Fe}$. In this case, soil $\mathrm{pH}$ affected As uptake indirectly via impact on available $\mathrm{P}$ and Fe. Wang et al. (2018) conducted a pot experiment to study the effect of $P$ application on the lability and phytoavailability of As in the soil and observed that application of exogenous phosphate induced soil arsenic mobilization, thereby increasing arsenic lability due to a competition effect. Finally, a positive correlation found between available P and total As in all soil layers is probably related to the fact that positively-charged colloidal surfaces that adsorb $\mathrm{P}$ in tropical agroecosystems are also relevant for retaining As in the soil system.

Extractable sulfur in this study affected negatively the amount of available As in the soil, in the layers 0-20 and 40-60 cm. The competition between $S$ and As, mainly in the $40-60 \mathrm{~cm}$ layer, where sulfur could have more affinity with the binding sites in tropical soils is relevant if we consider that As in soil solution cannot overcome $S$ in the sites available, due to a concentration effect, i.e., $\mathrm{S}$ in solution is generally higher than As in solution in most soils. Therefore the decreasing of available As in a long term is certain when the concentration of $\mathrm{S}$ is higher. But this is not the behavior often showed in experiments of shorter term where the addition of $\mathrm{S}$ displace As from the binding sites and increase its concentration in soil solution. In fact, Song et al. (2015) studying the effect of sulfate on As mobility in contaminated soils observed that addition of sulfate significantly enhanced As availability. Moreover, in a study aiming to evaluate the competitive adsorption of arsenate/phosphate and arsenate/sulfate in Brazilian soils, Campos et al. (2013a) observed that the addition of phosphate and sulfate decreased arsenate adsorption and consequently increased the concentration of As in soil solution and its availability.
The negative correlation between OM and available As in the 20-40 and 40-60 cm layers observed in the present study (Table 3), suggest that OM can be considered a trap and should be able to alleviate As mobility in soil by formation of covalent bindings, especially in OM-rich soils which is the case of some points sampled in these sites studied (Langner et al., 2012).

The adsorption capacity of As by soils provides an indication of the system's buffer power, since many soil attributes (such as texture, Fe and $\mathrm{Al}$ oxide content, among others) interfere with the buffer capacity and, consequently, influence leaching losses (Campos et al., 2013a). Although we did not find any relevant correlation among Fe and As fractions in soils from the present study, a great number of studies in the literature shows otherwise. In fact, a close coupling between the biogeochemical cycles of iron and arsenic in both oxidizing and reducing environment has been well established (Dixit and Hering, 2003). The mechanism that is presumably involved in this interaction is that both As(III) and As (V) adsorb to iron (hydr) oxides through, in part, formation of inner-sphere complexes (Tufano et al., 2008). Wang et al. (2012), studying As retention in muddy sediments observed that As retention was strongly coupled to Fe and S, and correlation analysis showed that total and extractable As correlated positively and well with total $\mathrm{Fe}$ and $\mathrm{HCl}$-extractable $\mathrm{Fe}$.

Fig. 6 shows the gradient of influence of the soil chemical variables and correlation groups of the samples for each site studied in the Amazon region. The model including the two principal components accounted for $52.7 \%$ of the total variance explained in the three layers studied (29.8\% for PC1 and $22.9 \%$ for PC2).

The first component (PC1) was negatively dominated by $\mathrm{P}, \mathrm{S}, \mathrm{K}$, total As, available As, soluble As, CEC, OM, Al and Fe and positively dominated by $\mathrm{Zn}, \mathrm{Mn}, \mathrm{Cu}, \mathrm{B}, \mathrm{Mg}, \mathrm{Ca}$ and $\mathrm{pH}$, which accounted for $29.8 \%$ of the variance. The second (PC2) was negatively dominated by $\mathrm{S}$ and positively dominated by $\mathrm{Fe}, \mathrm{OM}, \mathrm{Al}, \mathrm{AS}, \mathrm{CEC}$, soluble $\mathrm{As}$, available As, $\mathrm{K}$ and $\mathrm{P}$, representing $22.9 \%$ of the total variance in the data (Fig. 6).

The soil attribute with the biggest contribution for PC1 is soil $\mathrm{pH}$, followed by $\mathrm{Ca}$ and $\mathrm{Mg}$, i.e., in terms of acidity and the presence of basic cations, soils from the Amazon are very diverse, reflecting a heterogeneous mineralogy and capacity to adsorb anions as can be observed by the groupings of sites formed along the axis of these attributes (Fig. $6 \mathrm{~B}$ ). The soil attribute that contributed the most for PC2 is $\mathrm{Zn}$, followed by $\mathrm{K}$ and $\mathrm{P}$, which are influencing the grouping of the samples from the site XP.

Total, soluble, and available As are positively correlated with K, P, $\mathrm{CEC}, \mathrm{OM}, \mathrm{Al}$ and $\mathrm{Fe}$ and also present a major influence in the samples of the sites ANO, XP and SM. The close correlation between the As fractions and CEC and OM suggest that these soil properties are important factors to retain these As forms in the soil. With regard to CEC, unless there is a formation of a ternary complex in the interface soil-solution with an intermediate cation in the system, we believe that the correlation between CEC and As fractions is indirectly influenced by soil organic matter. The extractable $S$ was separated from the other soil chemical attributes in the third quadrant and showed no relationship with total and soluble As, and only a weak relationship with available As (negative correlation in the 0-20 and 40-60 cm layers) (Table 3) and therefore represented a major influence for the samples from the sites AR and PA (Fig. 6).

The site AP forms a separated group in the border of first and fourth quadrant, which indicates that this site present its chemistry distinct from the others, mainly because of the higher values of $\mathrm{pH}, \mathrm{Ca}, \mathrm{Mg}, \mathrm{B}$, $\mathrm{Mn}$, and $\mathrm{Cu}$. On the other hand, this site receives lower impact from the total, soluble and available As fractions because of its lower As concentrations compared with the other sites (Fig. 6). In summary, soil pH in combination with CEC and OM might be the key factors that influence total As concentrations in soil for the conditions of the present study. 


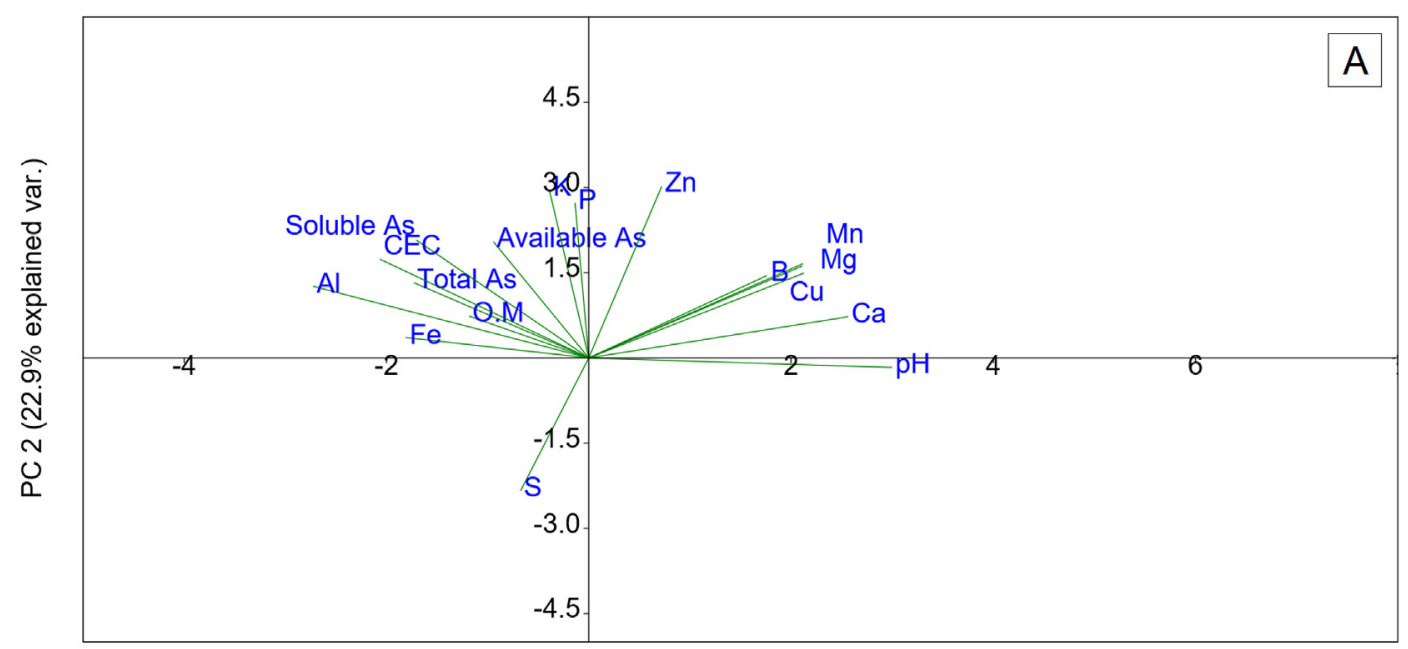

PC 1 (29.8\% explained var.)

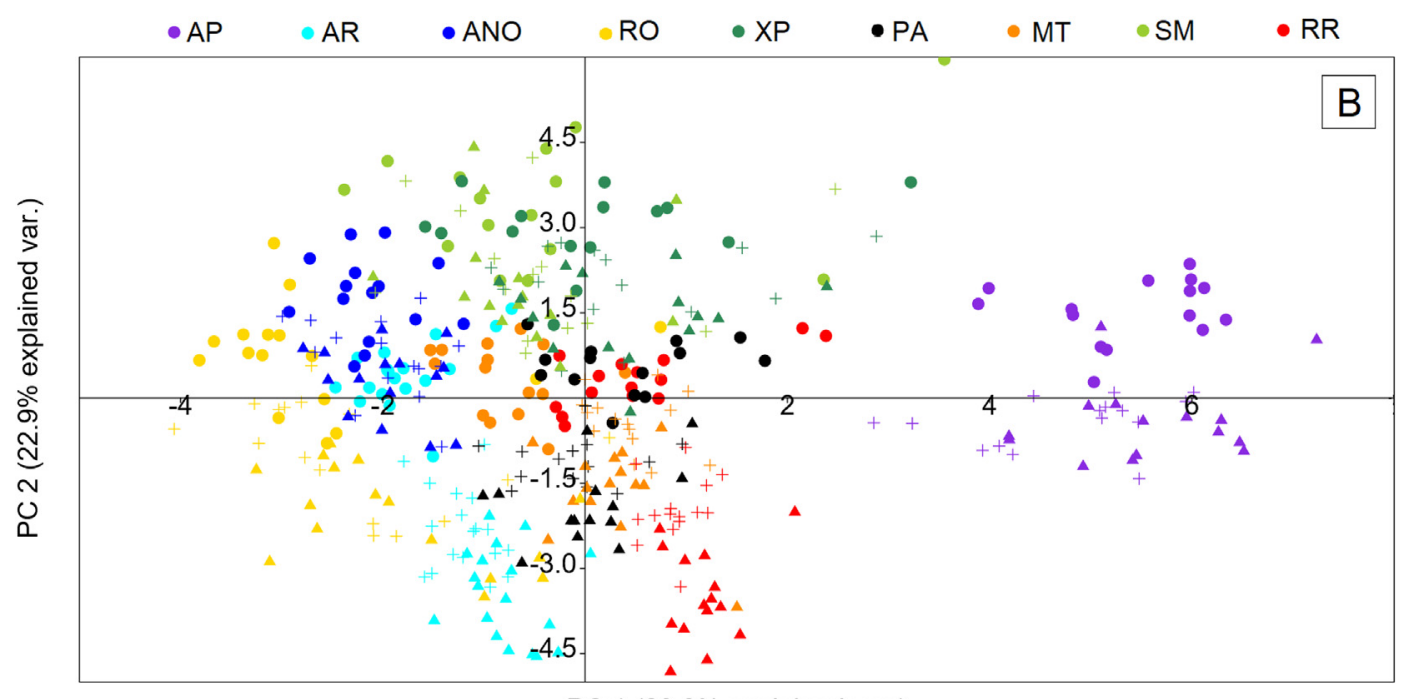

PC 1 (29.8\% explained var.)

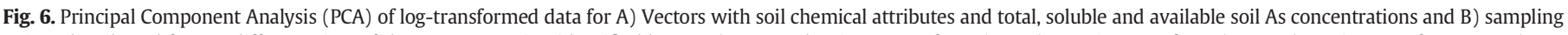

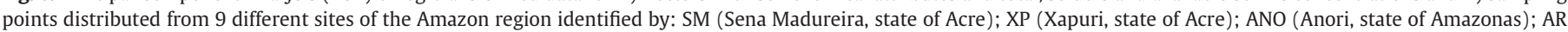

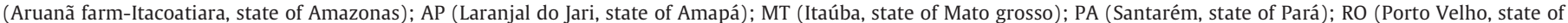

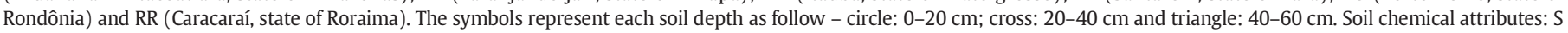

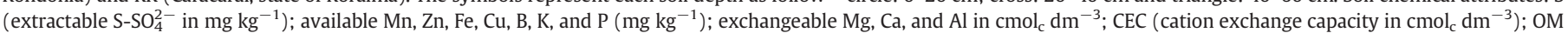
(organic matter in \%); $\mathrm{pH}\left(\mathrm{pH}\right.$ in $\left.\mathrm{H}_{2} \mathrm{O}\right)$; total As $\left(\mathrm{mg} \mathrm{kg}^{-1}\right)$; soluble As $\left(\mu \mathrm{g} \mathrm{kg}{ }^{-1}\right)$; available $\mathrm{As}\left(\mu \mathrm{kg}^{-1}\right)$. Graphic was designed using the software PAST (Hammer et al., 2001).

\section{Conclusions}

Soil $\mathrm{pH}$ and CEC are indirectly the main chemical attributes influencing the dynamic of As fractions in soils from the sites studied in the Amazon basin. In a smaller magnitude but not less important, the competing anions $\mathrm{P}$ and $\mathrm{S}$ affect soluble as well as available As in the soil.

The highest variable correlating with total, soluble and available As is soil $\mathrm{Al}^{3+}$ in the three layers studied. The mechanisms by which this element affect As mobility and retention needs further investigation, but might be related to formation of ternary complexes.

Our study raises the need to complement the information about the background levels of As in soils from the Amazon region using representative soils that reflects the natural concentrations of each sub-region in order to provide guideline values for a better use of soil and water resources in the region.

\section{Acknowledgements}

The authors are grateful to CNPq, CAPES and FAPEMIG from Brazil for financial support to the research project and especially CAPES for granting the doctorate scholarship for ECSJ. This study was financed in part by the Coordenação de Aperfeiçoamento de Pessoal de Nível Superior - Brasil (CAPES) - Finance Code 001.

GCM would like to thank for his Post-Doc scholarship provided by CAPES (Grant number 88887.160998/2017-00).

ARR also thanks the National Council for Scientific and Technological Development (Conselho Nacional de Desenvolvimento Científico e Tecnológico - CNPq) for the research fellowship (Grant number 309380/2017-0).

\section{Appendix A. Supplementary data}

Supplementary data to this article can be found online at https://doi. org/10.1016/j.scitotenv.2019.05.446.

\section{References}

Abdul, K.S.M., Jayasinghe, S.S., Chandana, E.P.S., Jayasumana, C., De Silva, P.M.C.S., 2015. Arsenic and human health effects: a review. Environ. Toxicol. Pharmacol. 40, 828-846. 
Adriano, D.C., 2001. Trace Elements in Terrestrial Environments: Biogeochemistry, Bioavailability, and Risks of Metals. 2nd. ed. Springer-Verlag New York, New York, USA.

Alam, M.G.M., Tokunaga, S., Stagnitti, F., 2007. Removal of arsenic from contaminated soils using different salt extractants. J. Environ. Sci. Heal. Part A 42, 447-451.

Alvarez, V.V.H.R.F., Novais, N.F., Barros, R.B., Cantarutti, A., Lopes, S., Alvarez, V.V.H., 1999. Interpretation of soil analysis results. In: Ribeiro, A.C., PTG, Guimarães (Eds.), Recommendations for Use of Amendments and Fertilizers in Minas Gerais, Brazil, 5aㅡ ed, pp. 25-32 Viçosa. (In Portuguese).

Alves, R.H., Rietzler, A.C., 2015. Efeitos tóxicos de arsênio em eisenia andrei em exposição a solos do entorno de minerações de ouro. Rev. Bras. Cienc. do Solo 39, 682-691.

Arco-Lázaro, E., Pardo, T., Clemente, R., Bernal, M.P., 2018. Arsenic adsorption and plant availability in an agricultural soil irrigated with As-rich water: effects of Fe-rich amendments and organic and inorganic fertilisers. J. Environ. Manag. 209, 262-272.

Baroni, F., Boscagli, A., Di Lella, L.A., Protano, G., Riccobono, F., 2004. Arsenic in soil and vegetation of contaminated areas in southern Tuscany (Italy). J. Geochemical Explor. 81, 1-14.

Biswas, A., Petter, J., Neidhardt, H., Halder, D., Kundu, A.K., Chatterjee, D., Berner, Z., 2014. Role of competing ions in the mobilization of arsenic in groundwater of Bengal basin: insight from surface complexation modeling. Water Res. 55, 30-39.

Borba, R.P., Figueiredo, B.R., Matschullat, J., 2003. Geochemical distribution of arsenic in waters, sediments and weathered gold mineralized rocks from Iron Quadrangle, Brazil. Environ. Geol. 4, 39-52.

Bundschuh, J., Litter, M.I., Parvez, F., Román-Ross, G., Nicolli, H.B., Jean, J.S., Liu, C.W., López, D., Armienta, M.A., Guilherme, L.R.G., Cuevas, A.G., Cornejo, L., Cumbal, L., Toujaguez, R., 2012. One century of arsenic exposure in Latin America: a review of history and occurrence from 14 countries. Sci. Total Environ. 429, 2-35.

Cai, Y., Cabrera, J.C., Georgiadis, M., Jayachandran, K., 2002. Assessment of arsenic mobility in the soils of some golf courses in South Florida. Sci. Total Environ. 291, 123-134.

Campos, M.L., Guilherme, L.R.G., Lopes, R.S., Antunes, A.S., Marques, J.J.G. de S. e M., Curi, N., 2007. Teor e capacidade máxima de adsorção de arsênio em Latossolos brasileiros. Rev. Bras. Ciência do Solo 31, 1311-1318.

Campos, M.L., Guilherme, L.R.G., Antunes, A.S., Borges, K.S.C., 2013a. Teor de arsênio e adsorção competitiva arsênio/fosfato e arsênio/sulfato em solos de Minas Gerais, Brasil. Ciência Rural 43, 985-991.

Campos, M.L., Guilherme, L.R.G., Marques, J.J.G. de S.e.M., Curi, N., Araújo, A.S.A., Miquelluti, D.J., Lopes, C., Spiazzi, F.R., 2013b. Teores de arsênio e cádmio em solos do bioma Cerrado. Rev. Bras. Cienc. do Solo 37, 281-286.

Carter, M.R., Gregorich, E.G., 2006. Soil Sampling and Methods of Analysis. $2^{\circ}$. ed. CRC Press. Canadian Society of Soil Science (1224 p).

Chatterjee, D., Adak, S., Banerjee, N., Bhattacharjee, P., Bandyopadhyay, A.K., Giri, A.K., 2018. Evaluation of health effects, genetic damage and telomere length in children exposed to arsenic in West Bengal, İndia. Mutat. Res. - Genet. Toxicol. Environ. Mutagen. 836, 82-88.

Chilimba, A.D.C., Young, S.D., Black, C.R., Rogerson, K.B., Ander, E.L., Watts, M.J., Lammel, J., Broadley, M.R., 2011. Maize grain and soil surveys reveal suboptimal dietary selenium intake is widespread in Malawi. Sci. Rep. 1-9.

Chowdhury, M.T.A., Deacon, C.M., Steel, E., Imamul Huq, S.M., Paton, G.I., Price, A.H., Williams, P.N., Meharg, A.A., Norton, G.J., 2018. Physiographical variability in arsenic dynamics in Bangladeshi soils. Sci. Total Environ. 612, 1365-1372.

Cleasby, I.R., Nakagawa, S., 2011. Neglected biological patterns in the residuals. Behav. Ecol. Sociobiol. 65, 2361-2372.

Conama, 2009. Normative No. 420 of December 28th, 2009. Valores Orientadores de Qualidade do Solo Quanto a Presença de Substâncias Químicas, Conselho Nacional de Meio Ambiente, 2009. Accessed Dec 03, 2018 from http://www2.mma.gov.br/ port/conama/legiabre.cfm?codlegi $=620$.

Da Silva, W.B., Périco, E., Dalzochio, M.S., Santos, M., Cajaiba, R.L., 2018. Are litterfall and litter decomposition processes indicators of forest regeneration in the neotropics? Insights from a case study in the Brazilian Amazon. For. Ecol. Manag. 429, 189-197.

De Souza, J.J.L.L., Fontes, M.P.F., Gilkes, R., da Costa, L.M., de Oliveira, T.S., 2018. Geochemical signature of Amazon tropical rainforest soils. Rev. Bras. Cienc. do Solo 42, 1-18.

Dixit, S., Hering, J.G., 2003. Comparison of arsenic (V) and arsenic (III) sorption onto iron oxide minerals: implications for arsenic mobility. Environ. Sci. Technol. 37, 4182-4189.

Empresa Brasileira de Pesquisa Agropecuária - Embrapa, 1997. Manual de métodos de análise de solo. 2.ed. Rio de Janeiro. (212p).

Fadini, P.S., Jardim, W.F., 2001. Is the Negro River Basin (Amazon) impacted by naturally occurring mercury? Sci. Total Environ. 275, 71-82.

Fernandes, A.R., Souza, E.S. de, de Souza Braz, A.M., Birani, S.M., Alleoni, L.R.F., 2018. Quality reference values and background concentrations of potentially toxic elements in soils from the eastern Amazon, Brazil. J. Geochemical Explor. 190, 453-463.

Fontes, M.P.F., Camargo, O.A. de, Sposito, G., 2001. Eletroquímica das partículas coloidais e sua relação com a mineralogia de solos altamente intemperizados. Sci. Agric. 58, 627-646.

Gamboa-Loira, B., Cebrián, M.E., Franco-Marina, F., López-Carrillo, L., 2017. Arsenic metabolism and cancer risk: a meta-analysis. Environ. Res. 156, 551-558.

Hammer, Ø., Harper, D.A.T., Ryan, P.D., 2001. PAST: Paleontological statistics software package for education and data analysis. Palaeontol. Electron. 4 (1), 9. http:// palaeo-electronica.org/2001_1/past/issue1_01.htm.

He, Q., Ren, Y., Mohamed, I., Ali, M., Hassan, W., Zeng, F., 2013. Assessment of trace and heavy metal distribution by four sequential extraction procedures in a contaminated soil. Soil Water Res. 8, 71-76.
Ho, H.H., Swennen, R., Cappuyns, V., Vassilieva, E., Van Gerven, T., Van Tran, T., 2013. Speciation and mobility of selected trace metals ( $\mathrm{As}, \mathrm{Cu}, \mathrm{Mn}, \mathrm{Pb}$ and $\mathrm{Zn}$ ) in sediment with depth in Cam River-Mouth, Haiphong, Vietnam. Aquat. Geochemistry 19, 57-75.

Huang, R., Gao, S., Wang, W., Staunton, S., Wang, G., 2006. Soil arsenic availability and the transfer of soil arsenic to crops in suburban areas in Fujian Province, Southeast China. Environ. Process. 368, 531-541.

Jiang, W., Hou, Q., Yang, Z., Zhong, C., Zheng, G., Yang, Z., Li, J., 2014. Evaluation of potential effects of soil available phosphorus on soil arsenic availability and paddy rice inorganic arsenic content. Environ. Pollut. 188, 159-165.

Kabata-Pendias, A., 2011. Trace Elements in Soils and Plants. 4th ed. CRC Press LLC, USA.

Kabata-Pendias, A., Mukherjee, A.B., 2007. Trace Elements From Soil to Human. SpringerVerlag, Berlin.

Kapaj, S., Peterson, H., Liber, K., Bhattacharya, P., 2006. Human health effects from chronic arsenic poisoning-a review. J. Environ. Sci. Heal. 41, 2399-2428.

Kim, K., Kim, J., Davis, A.P., 2003. Stabilization of available arsenic in highly contaminated mine tailings using iron. Environ. Sci. Technol. 37, 189-195.

Langner, P., Mikutta, C., Kretzschmar, R., 2012. Arsenic sequestration by organic sulphur in peat. Nat. Geosci. 5, 66-73.

Lenth, R.V., 2016. Least-squares means: the R package lsmeans. J. Stat. Softw. 69, 1-33.

Liu, L., Li, W., Song, W., Guo, M., 2018. Remediation techniques for heavy metalcontaminated soils: principles and applicability. Sci. Total Environ. 633, 206-219.

McBride, M.B., 1994. Environmental Chemistry of Soils. Oxford University, New York.

Meliker, J.R., Wahl, R.L., Cameron, L.L., Nriagu, J.O., 2007. Arsenic in drinking water and cerebrovascular disease, diabetes mellitus, and kidney disease in Michigan: a standardized mortality ratio analysis. Environ. Health 6,1-11.

Melo, É.E.C., Guilherme, L.R.G., Nascimento, C.W.A., Penha, H.G.V., 2012. Availability and accumulation of arsenic in oilseeds grown in contaminated soils. Water Air Soil Pollut. 223, 233-240.

Minatel, B.C., Sage, A.P., Anderson, C., Hubaux, R., Marshall, E.A., Lam, W.L., Martinez, V.D. 2018. Environmental arsenic exposure: from genetic susceptibility to pathogenesis. Environ. Int. 112, 183-197.

Naujokas, M.F., Anderson, B., Ahsan, H., Vasken Aposhian, H., Graziano, J.H., Thompson, C. Suk, W.A., 2013. The broad scope of health effects from chronic arsenic exposure: update on a worldwide public health problem. Environ. Health Perspect. 121, 295-302.

Oliveira, LK. De, Melo, CA Goveia, D. Lobo, A Aurora, M. Hernández, A., Fernandes, L Rosa, A.H., 2015. Adsorption/desorption of arsenic by tropical peat: influence of organic matter, iron and aluminium. Environ. Technol. 36, 149-159.

Ono, F.B., Guilherme, L.R.G., Penido, E.S., Carvalho, G.S., Hale, B., Toujaguez, R., Bundschuh, J., 2012. Arsenic bioaccessibility in a gold mining area: a health risk assessment for children. Environ. Geochem. Health 34, 457-465.

Punshon, T., Jackson, B.P., Meharg, A.A., Warczack, T., Scheckel, K., Guerinot, M. Lou, 2017. Understanding arsenic dynamics in agronomic systems to predict and prevent uptake by crop plants. Sci. Total Environ. 581-582, 209-220.

R Development Core Team, 2018. R: A Language and Environment for Statistical Computing. R Foundation for Statistical Computing, Vienna, Austria (Version 3.4.4).

Rahman, M.A., Rahman, A., Khan, M.Z.K., Renzaho, A.M.N., 2018. Human health risks and socio-economic perspectives of arsenic exposure in Bangladesh: a scoping review. Ecotoxicol. Environ. Saf. 150, 335-343.

Raij, B.van., Quaggio, J.A., 1983. Métodos de análise de solo para fins de fertilidade (Boletim Técnico, 81). Instituto Agronômico, Campinas (31 p).

Shahmoradi, S., Afyuni, M., Hajabbasi, M.A., 2017. Speciation, fractionation and plant availability of arsenic as induced by sorbents mixed with soil of Zarshuran (Iran). Int. J. Environ. Sci. Technol. 14, 767-776.

Sharma, P., Ofner, J., Kappler, A., 2010. Formation of binary and ternary colloids and dissolved complexes of organic matter, Fe and As. Environ. Sci. Technol. 44 4479-4485.

Sharma, P., Rolle, M., Kocar, B.D., Fendorf, S., Kapppler, A., 2011. Influence of natura organic matter on As transport and retention. Environ. Sci. Technol. 45, $546-553$.

Shoemaker, H.E., McLean, E.O., Pratt, P.F., 1961. Buffer methods for determining lime requirement of soils with appreciable amounts of extractable aluminum. Soil Science Society of American Proceeding, Madison 25, 274-277.

Silva Junior, E.C., Wadt, L.H.O., Silva, K.E., Lima, R.M.B., Batista, K.D., Guedes, M.C. Carvalho, G.S., Carvalho, T.S., Reis, A.R., Lopes, G., Guilherme, L.R.G., 2017. Natural variation of selenium in Brazil nuts and soils from the Amazon region. Chemosphere 188 650-658.

Song, Y., Wang, S., Jia, Y., Yuan, Z., Wang, X., Goméz, M.A., 2015. Effects of nutrient and sulfate additions on As mobility in contaminated soils: a laboratory column study Chemosphere 119, 902-909.

Thinh, N. Van, Osanai, Y., Adachi, T. Thai, P. K, Nakano, N., Ozaki, A., Kuwahara, Y., Kato, R. Makio, M., Kurosawa, K., 2018. Chemical speciation and bioavailability concentration of arsenic and heavy metals in sediment and soil cores in estuarine ecosystem, Vietnam. Microchem. J. 139, 268-277.

Tufano, K.J., Reyes, C., Saltikov, C.W., 2008. Reductive processes controlling arsenic retention: revealing the relative importance of iron and arsenic reduction. Environ. Sci. Technol. 42, 8283-8289.

Van Herreweghe, S., Swennen, R., Vandecasteele, C., Cappuyns, V., 2003. Solid phase speciation of arsenic by sequential extraction in standard reference materials and industrially contaminated soil samples. Environ. Pollut. 122, 323-342.

Wan, X., Dong, H., Feng, L., Lin, Z., Luo, Q., 2017. Comparison of three sequential extraction procedures for arsenic fractionation in highly polluted sites. Chemosphere 178 402-410.

Wang, S., Xu, L., Zhao, Z., Wang, S., Jia, Y., Wang, H., Wang, X., 2012. Arsenic retention and remobilization in muddy sediments with high iron and sulfur contents from a heavily contaminated estuary in China. Chem. Geol. 314-317, 57-65. 
Wang, J., Zeng, X., Zhang, H., Li, Y., Zhao, S., Su, S., Bai, L., Wang, Y., Zhang, T., 2018. Effect of exogenous phosphate on the lability and phytoavailability of arsenic in soils. Chemosphere 196, 540-547.

Wenzel, W.W., Kirchbaumer, N., Prohaska, T., Stingeder, G., Lombi, E., Adriano, D.C., 2001. Arsenic fractionation in soils using an improved sequential extraction procedure. Anal. Chim. Acta 436, 309-323.
WHO, 2001. Environmental Health Criteria 224, Arsenic and Arsenic Compounds. Interorganization Programme for the Sound Management of Chemicals. Geneva.

Zhang, L., Qin, X., Tang, J., Liu, W., Yang, H., 2017. Review of arsenic geochemical characteristics and its significance on arsenic pollution studies in karst groundwater, Southwest China. Appl. Geochem. 77, 80-88. 